\title{
Anthropogenic and geogenic influences on peri-urban aquifers in semi-arid regions: insights from a case study in northeast Jaipur, Rajasthan, India
}

\author{
Theresa Frommen $^{1}$ (D) $\cdot$ Maike Groeschke $^{2}$ (D) $\cdot$ Maximilian Nölscher $^{2} \cdot$ Paul Koeniger $^{2}$ (D) $\cdot$ Michael Schneider $^{1}$
}

Received: 12 April 2020 / Accepted: 2 January 2021 / Published online: 2 February 2021

(C) The Author(s) 2021

\begin{abstract}
Rapid urbanization has exerted considerable pressure on groundwater resources in Jaipur, India. Peri-urban areas are particularly affected as the public supply infrastructure often does not reach this fast-growing fringe, which often lacks a planning strategy, leading to an informal water supply based on groundwater. At the same time, the hills and historic reservoirs located in these areas are important for groundwater recharge and, therefore, critical for sustainable groundwater-resource management. To understand the local hydrogeology and the role of anthropogenic influences, a 2-year field study was carried out in northeastern Jaipur. The aim was to develop a conceptual model on which a management concept can be built. The study comprised hydrochemical and stable isotope analyses of water samples, depth-to-water measurements, a leveling survey and geophysical investigations. The study revealed that the groundwater from both the Proterozoic hard rock and the overlying Quaternary alluvial aquifer generally does not meet the Indian drinking water thresholds for nitrate concentration and/or total dissolved solids (TDS). While anthropogenic activities are the main source of quantity problems (declining groundwater levels through overabstraction), the biggest quality problems (nitrate up to $550 \mathrm{mg} / \mathrm{L}$ and TDS $>500 \mathrm{mg} / \mathrm{L}$ ) are most likely of geogenic origin and only enhanced by anthropogenic impacts. Quantity and quality aspects improve significantly in areas influenced by recharge from the historic reservoirs, leading to the conclusion that artificial recharge structures may be the way forward to improving community water supply and that groundwater protection should be given priority in these areas.
\end{abstract}

Keywords Hydrochemistry $\cdot$ Groundwater management $\cdot$ Semi-arid regions $\cdot$ Urbanization $\cdot$ India

\section{Introduction}

In India, the growth rate of the urban population between 2000 and 2010 was $2.6 \%$, and by 2050 another 404 million Indian people are expected to live in cities (UN-Habitat and ESCAP 2015). The cities' fringes are most affected by this rapid growth in population (Howard 2014), as large peri-urban areas form, characterized as transitional zones of mixed rural and urban uses in terms of economic, social, cultural and natural resources (Phillips et al. 1999). The shift from rural to urban

Theresa Frommen

theresa.frommen@hu-berlin.de

1 Freie Universitaet Berlin, Hydrogeology Group, Malteserstr.74-100, 12249 Berlin, Germany

2 BGR - Federal Institute for Geosciences and Natural Resources, Berlin, Hannover, Germany has huge influences on the natural resources, including groundwater, and the prognosis of the development of groundwater resources is particularly challenging due to the interplay of various factors in the peri-urban environment. On one hand, water tables are decreasing in many urban areas in India (MacDonald et al. 2016), a trend that can also be observed in semiarid rural areas in Rajasthan (Yadav et al. 2016). On the other hand, urbanization can also lead to an increase in recharge rates, e.g. through leaking sewers and, hence, to rising water tables (Foster 2001). Furthermore, apart from direct anthropogenic impacts, meteorological patterns can play a significant role, especially in north-central and southern India (Asoka et al. 2017).

Peri-urban areas often serve as a source of water for cities in India and worldwide (Butterworth et al. 2007). Besides the water provided by the public water suppliers, which often use a significant share of groundwater in their supply schemes, a large part of the cities' demand is being served by an informal water market, in 
which groundwater is transported, for example via private tankers, from the outskirts to the city centers (Prakash and Singh 2014). This informal market makes it nearly impossible to manage the groundwater abstraction in a sustainable way. At the same time, peri-urban areas often function as disposal sites for wastewater from the cities. A failure to view the peri-urban space as a resource worth protecting and insufficient wastewater treatment capacities lead to the accumulation of wastewater in lakes, ponds and lowlands with the expected negative impacts on groundwater quality (Karpouzoglou et al. 2018). The lack of a sanitation and sewerage infrastructure in many unplanned periurban areas increases the effect of anthropogenic pollution of groundwater resources (Prakash and Singh 2014; Sekhar et al. 2005), which is typically characterized by elevated nitrate concentrations and occurrence of fecal pathogens (MacDonald et al. 2016; Yadav et al. 2016). In addition, groundwater in peri-urban areas can also be affected by agricultural activities, e.g. through the (over)application of fertilizers (Rao 2008) and pesticides (Hussain and Hanisch 2014), or by the use of intensive irrigation practices that can lead to an increase of the natural salinity (MacDonald et al. 2016).

Besides anthropogenic sources of contamination, geogenic contaminants regionally lead to a deterioration of groundwater quality. They are not restricted to periurban zones but may in cases complicate the use of groundwater in these areas. Besides high concentrations of fluoride, mostly found in northwestern and southern India (Podgorski et al. 2018), and arsenic-e.g. in large parts of the Indo-Gangetic plain and the Brahmaputra floodplain (Ghosh and Singh 2010) - elevated groundwater salinity is a frequent cause of concern in many parts of India, posing difficulties for both irrigation and drinking purposes (Bhardwaj 2005; MacDonald et al. 2016). Reasons are, besides the aforementioned irrigation practices, saline intrusion in coastal areas as well as historic marine influences, dissolution of evaporates and the evaporation of surface water and shallow groundwater.

To sum up, the processes within the peri-urban zone of Indian cities, influence groundwater availability and quality significantly; yet, to date, the importance of these areas for groundwater protection and management are often not recognized and therefore not considered in water management planning. This report presents the results of a detailed case study conducted in two peri-urban areas in northeast Jaipur. The goal was to understand the regional and local hydrogeology, identify the most relevant processes and develop a conceptual model to identify areas of special concern where water management solutions are especially important or would have a particularly large effect.

\section{Materials and methods}

\section{Study area}

Jaipur, the capital of the state Rajasthan in northwestern India, is situated between latitude 26.82 to $27.00^{\circ}$ and longitude 75.73 to $75.85^{\circ}$ (WGS 84) on the eastern border of the Thar Desert (Fig. 1). It is classified as a semiarid area with a longterm average annual rainfall of $565 \mathrm{~mm}$ in Jaipur district, based on data from 1977 to 2006 (CGWB 2013). In all, $90 \%$ of the annual rainfall takes place during the south-west monsoon from June to September (CGWB 2007). A high variability of the annual monsoonal precipitation amount (300-700 mm) can be observed (Yadav et al. 2016).

The city is situated within the Proterozoic Aravalli Mountain Range which extends over $700 \mathrm{~km}$ from North Gujarat in the SW up to Delhi in the NE (Sharma 2009). The steeply rising hills (up to $650 \mathrm{~m} \mathrm{NN}$ ) surrounding Jaipur from NE to $\mathrm{W}$ belong to the Alwar series of the Mesoproterozoic Northern Delhi Fold Belt and mainly consist of fractured and partly weathered quartzite. The Geological Survey of India (GSI 2011) reports for the Alwar series a feldspathic quartzite. In the occasionally wide valleys inbetween the NNE-SSW striking hills (GSI 2011) the bedrock is covered by Quaternary alluvial sediments, which can reach a thickness of up to $100 \mathrm{~m}$ (CGWB 2007). The alluvium does not only consist of fluvial sediments, but also aeolian sediments and denudational material close to the hills, leading to a wide range of sediments from silt and fine sand to coarse sand and gravel near the hills. Three fluvial phases during the Quaternary reworked the sediments and formed the landscape so that today buried river channels as well as undulating fluvial plains can be found (CGWB 2013; GSI 2011). Kankar layers, consisting of secondary calcite rich nodules, and clay lenses occur at various depths within the Quaternary alluvium (Antea International, unpublished report, 1999).

Two peri-urban communities situated in the NE of Jaipur in the subdistrict Amer were chosen as exemplary study areas due to their socio-economic, topographic and geologic heterogeneity. Khara Kuaa (KK) is a well-established Hindu community lying at the foothills of the Aravallis behind Amer Fort, where two historic water reservoirs are located. The main aquifer is the weathered part of the Proterozoic quartzite (fractured hard rock aquifer). The water demand is partly covered by public water supply (water from the surface-water dam Bisalpur mixed with local groundwater is supplied for $1 \mathrm{~h} /$ day or via tanker), by private water tanker (local groundwater) and by groundwater drawn from hand pumps. The second study area, Nai Ki Thari (NKT), is a Muslim community located in the flat plain $5 \mathrm{~km}$ outside of the current city boundary, which was developed only within the last 20 years. The main aquifer is the Quaternary alluvium. More than $95 \%$ of the water supply is based on local groundwater, as there are no public water supply connections. 


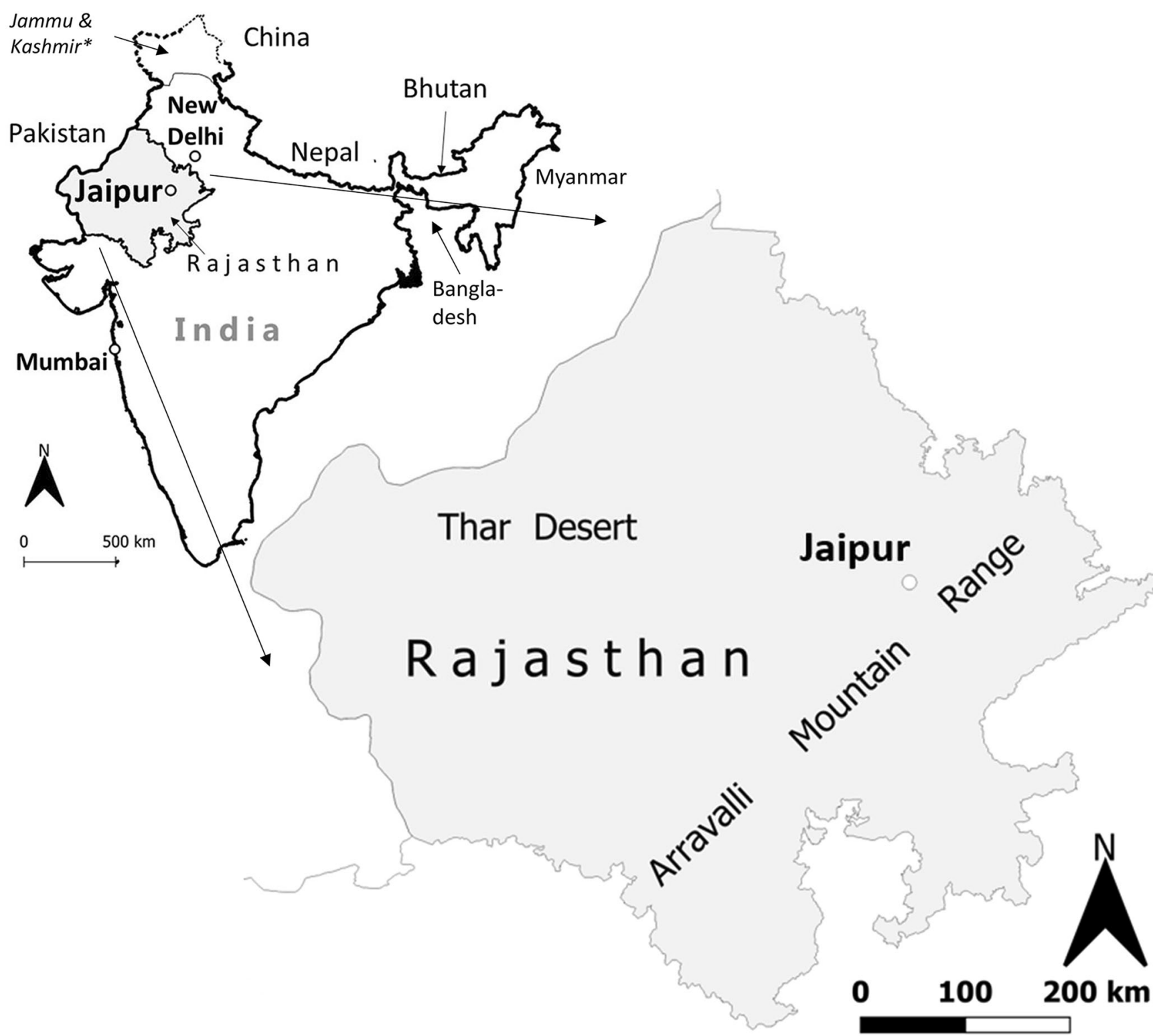

Fig. 1 Map of India, showing Rajasthan and its capital Jaipur, which is located at the eastern border of the Thar Desert. The Aravalli mountains stretch to Delhi. Dashed line represents approximately the Line of Control

\section{Data collection, mapping and well selection}

A detailed mapping of the water infrastructure was conducted to understand the role of groundwater in the target zones and to identify wells suitable for hydrogeological investigations. Mapping activities included interviews about how and where groundwater is used by whom and about possible sources of contamination (e.g. location, construction and maintenance of septic tanks). An emphasis was laid on surface-water bodies and their possible connection to the aquifer. Data regarding the design of the wells were collected during interviews with well owners and users, as no bore logs were available. between Pakistan and India; the final status of Jammu and Kashmir has not yet been agreed upon. Dotted line represents disputed borders

Wells for regular hydrochemical sampling were chosen according to the following criteria:

Condition. The well is in a good condition and the pump is working.

Permission. The well owner (private or public) agreed to a regular sampling.

Accessibility. The well is accessible by auto rickshaw or foot during all seasons.

Importance. The well has a high importance for the formal or informal water supply.

Distribution. Both communities and their surroundings are covered in a meaningful way by 
considering geology, surface-water bodies and possible contamination sources.

Depth. A large range of total depth of the wells is covered.

As no official piezometer (only one abandoned bore well used for this study as piezometer) was located within the study area, hand pumps and bore wells were selected as sampling points.

\section{Water sampling strategy}

Water samples were taken for analyses of major ions and stable isotopes of water. For hydrochemical analyses, 121 water samples were collected from a total of 34 wells and two surface-water bodies (Fig. 2) from November to December 2017 (Table 1). Thirty of these wells were chosen for regular sampling at a 3-5-month interval, the number varying slightly at each campaign due to some wells falling dry or pumps braking. Additionally, one rain sample was collected for a full hydrochemical analyses in January 2017.

At all wells, except the piezometer, the installed pumps (manual or electric) were used for sampling. Because of frequent power cuts, reluctance of well owners, wastage of water at private wells, or environmental conditions (manual pumping at $>40{ }^{\circ} \mathrm{C}$ ), prepumping was difficult at some sampling points. In such cases, sampling was conducted at the usual pumping times of the wells. In this way, it was guaranteed that the well was already running for more than $30 \mathrm{~min}$. The physicochemical parameters - temperature (T), electrical conductivity (EC), $\mathrm{pH}$, oxidation-reduction potential (ORP), dissolved oxygen $\left(\mathrm{O}_{2}\right)$ - were measured on-site by customary probes with a digital portable multimeter (Hach HQ40D). After a complete screening in the first sampling campaign, colorimetric tests to determine redox-sensitive species- (ammonium $\left(\mathrm{NH}_{4}{ }^{+}\right)$, nitrite $\left(\mathrm{NO}_{2}{ }^{-}\right)$, nitrate $\left(\mathrm{NO}_{3}{ }^{-}\right)$, sulfide $\left(\mathrm{S}_{2}{ }^{-}\right)$-were applied in the field wherever necessary (Table S1 of electronic supplementary material, ESM). Bicarbonate was determined using a titrimetric test (accuracy $0.2 \mathrm{mmol} / \mathrm{L}$ ). All samples were filtered through a $0.2-\mu \mathrm{m}$ polyethersulfone membrane filter and samples for cation analysis were acidified with ultra-pure $60 \%$ nitric acid to $\mathrm{pH}<2$, before being filled in polyethylene bottles and stored under cold conditions. The storage period lasted from a few days up to 1 month. Cations were analyzed by ICP-OES (Optima 2100 PerkinElmer) and anions by ion chromatography (Dionex ICS 1100 ) at the hydrogeochemical laboratory at the Institute of Geological Science, Freie Universitaet Berlin, Germany. Samples showing a charge balance error (CBE) below $10 \%$ were considered for further analysis (King et al. 2014).

A total of 152 water samples for stable isotope analysis were taken between November 2016 and October 2018. Out of the 152 samples, 112 are groundwater samples, 28 surface- water samples and 12 rain samples. Surface-water samples were taken regularly from two historic reservoirs and one taalaab (lake, where greywater from the surrounding area gets accumulated) and once from two canals (nallahs). The sampling at the lakes was mainly carried out with a 2-L plastic bucket connected to a 1.5 -m-long stick. Rain samples were taken on top of a small building to the east of Jaipur City (Lat: $26.903073^{\circ}$, Long: $75.841136^{\circ}$ ) with a self-made rain isotope collector using the design by Gröning et al. (2012). The samples were collected during seven rainfall events during the monsoon season 2017 and at single rainfall events in January and March 2017. They were filled in tightly sealed glass vials without pretreatment and stored in a dark and cool place until analysis (Picarro L2120-i cavity ringdown analyzer) at the BGR laboratory in Hannover, Germany. All samples were analyzed as replicates, drift-corrected and calculated against international standards (VSMOW/VSLAP). The values are given as $\delta$-value in $\%$. Analytical error for a quality check sample measured in each sequence is better than 0.2 and $0.8 \%$ or $\delta^{18} \mathrm{O}$ and $\delta^{2} \mathrm{H}$, respectively.

\section{Depth-to-water measurements, leveling and geophysical survey}

For the regular water-table measurements every 2 months, 30 50 wells were chosen within both communities and their surroundings ( $\sim 30 \mathrm{~km}^{2}$, elevation difference of about $\left.45 \mathrm{~m}\right)$ including hand pumps, piezometers, bore wells, dug wells and step wells. The number of wells varied slightly from campaign to campaign as some wells went dry, were closed, or were completely overgrown. A water level data logger (Solinst) was installed in an unused hand pump tapping the fractured quartzite aquifer. A leveling survey was conducted to determine the absolute elevation of the 31 most important wells. The applied D-GPS Leica Viva GS14 system can give, under favorable conditions, a horizontal accuracy of $8 \mathrm{~mm}+1 \mathrm{ppm}$ and a vertical of $15 \mathrm{~mm}+1 \mathrm{ppm}$ when applying the RTK mode (real time kinematic) with a single baseline (Leica 2016). To get more information about the thickness of the Quaternary alluvial sediments/aquifer and the distribution of thickness of possible clay layers, 30 geoelectrical resistivity soundings were conducted in Nai Ki Thari. The soundings were recorded with a computerized resistivity meter CRM500 and the Schlumberger's configuration was adopted.

\section{Statistical methods for hydrochemical facies interpretation}

Multivariate statistical analysis (MSA) was applied and compared to graphical methods (Durov plots, binary plots). For that, the original data base was edited. As a first step, only the groundwater samples from one sampling campaign (October 2017) were used to avoid duplicates which could lead to an 

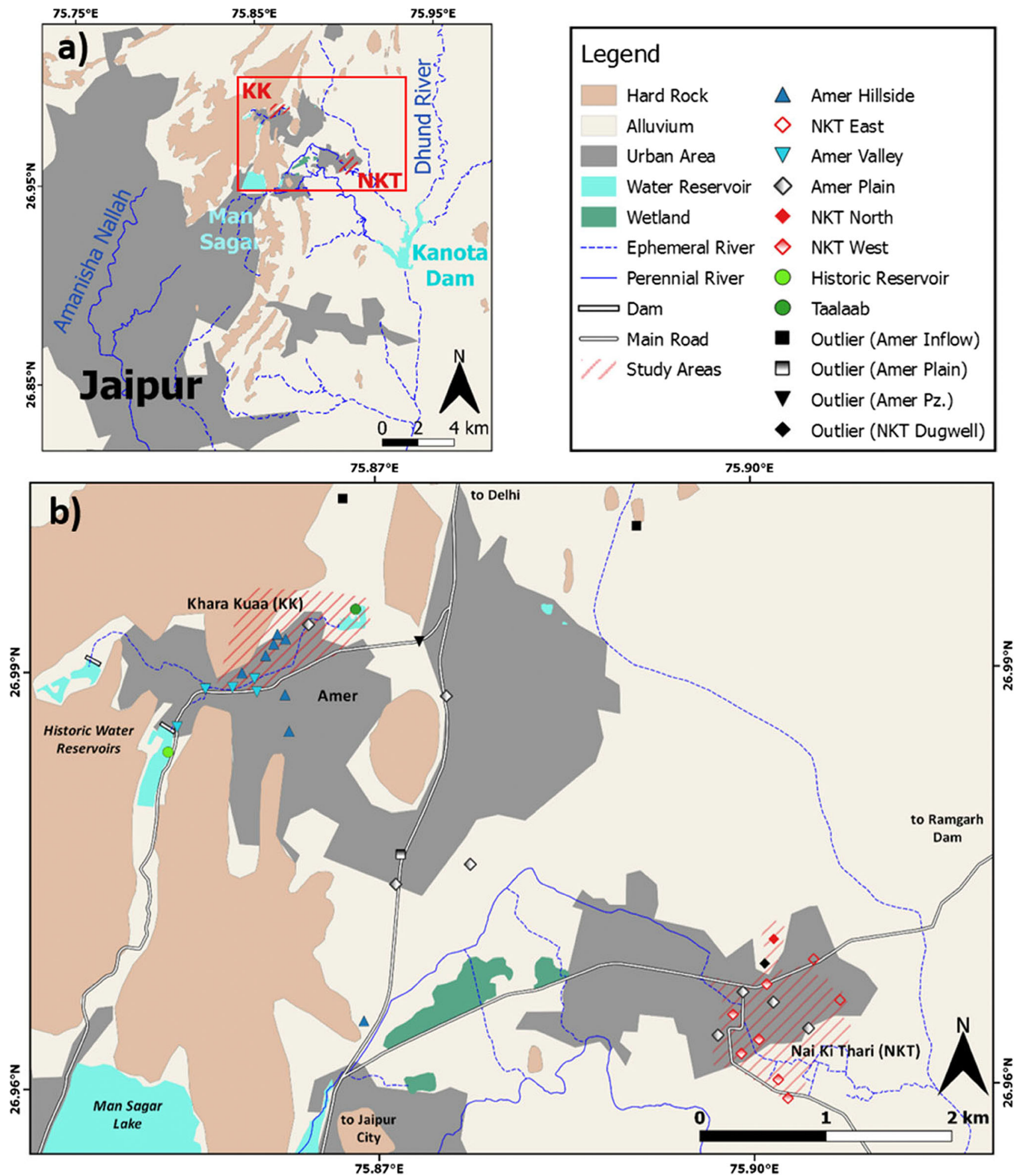

Fig. 2 Maps showing $\mathbf{a}$ the locations of the study areas, and $\mathbf{b}$ the wells and surface-water bodies used for regular hydrochemical sampling according to the hydrochemical groups determined by HCA

overestimation for certain wells. The October 2017 sampling campaign was chosen because all samples of this campaign show a $\mathrm{CBE}$ within $\pm 3 \%$. Regarding the input parameters, the variables were reduced to 17 variables (main ions, $\mathrm{EC}, \mathrm{pH}$, $\mathrm{O}_{2}, \mathrm{Br}, \mathrm{Sr}, \mathrm{Zn}, \mathrm{F}, \mathrm{Ba}, \mathrm{B}$ ) including only variables with results for all samples (Güler et al. 2002). Values below the detection 
Table 1 Number and type of wells for the sampling campaigns

\begin{tabular}{lllll}
\hline Type of sampling point & $\begin{array}{l}\text { Nov/ } \\
\text { Dec 2016 } \\
\text { winter }\end{array}$ & $\begin{array}{l}\text { Apr 2017 } \\
\text { pre-monsoon }\end{array}$ & $\begin{array}{l}\text { Oct 2017 } \\
\text { post-monsoon }\end{array}$ & $\begin{array}{l}\text { Dec 2017 } \\
\text { winter }\end{array}$ \\
\hline Bore well & 16 & 13 & 14 & 11 \\
Hand pump & 11 & 12 & 14 & 14 \\
Bore well (water supplier) & 2 & 2 & 2 & 1 \\
Dug well & 2 & 1 & 0 & 0 \\
Piezometer & 1 & 1 & 0 & 0 \\
Lake & 1 & 0 & 2 & 0 \\
Rain & 1 & 0 & 0 & 0 \\
Total & 34 & 29 & 32 & 26 \\
\hline
\end{tabular}

limit were replaced by multiplying the respective lower detection limit with 0.55 to avoid nonnumerical values. This simple substitution method is possible if the data set shows only a small portion $(<10 \%)$ of censored values (Sanford et al. 1993) and if the choice of the substitution method does not have an effect on the final geochemical interpretation (Miesch and Barnett 1976). In a subsequent step, descriptive statistics were calculated and histograms were generated using the statistical software statistiXL 2.0, which can be used as an add-in with Microsoft Excel. Based on this, the data were checked for normal distribution as multivariate statistical methods assume a normal distributed data set. As a result, all variables, except $\mathrm{EC}, \mathrm{pH}$ and $\mathrm{Ba}$, were log-transformed to achieve a more normal distribution. Both, the transformed and the untransformed values were then standardized by calculating their standard scores to guarantee that all variables are equally weighted in the following multivariate statistical calculations regardless of their magnitude (Güler et al. 2002).

Hierarchical cluster analysis (HCA) was chosen as it provides the possibility to generate homogenous groups, which helps to define hydrochemical facies (Newman et al. 2016). The distance/similarity measure was calculated with the squared Euclidean distance method. In order to avoid a tendency in the subsequent analysis, the HCA was first performed with the nearest neighbor clustering method with which outliers can be identified (Daughney and Reeves 2005, King et al. 2014). Subsequently, the clustering was performed following Ward's method. Güler et al. (2002) had shown that the combination of these methods gives best results for hydrochemical data. Next to the distance matrix and the clustering strategy, results of the HCA are displayed as a dendrogram giving a visual summary of the grouping. To avoid an unpractically large number of groups and subgroups in the HCA, four locations were classified as outliers in the HCA (KK_OBS02, KK_BW08, NKT_DW02, Amer Inflow) due to their greatly differing chemical properties.

\section{Results}

Out of the 121 water samples taken in total for hydrochemical analysis (Table 1; Table S2 of ESM), 93 samples are used for further interpretation based on their belonging to the regular sampling campaigns and on their analytical accuracy $(\mathrm{CBE}<10 \%)$.

\section{Hydrochemical and hydrogeological characterization}

\section{Identification of hydrochemical groups}

Based on the HCA, which was conducted with groundwater samples from 34 locations, it was possible to distinguish two groups. Group 1 represents samples associated with the Proterozoic hard rock aquifer and group 2 is associated with the Quaternary alluvial aquifer. A third group represents surface-water samples from two locations (Table 2). Plotting the HCA groups and outliers on a map, reveals that they roughly represent the two study areas generally matching the occurrence of the respective aquifers (Fig. 2). However, there are some deviations: (1) the easternmost part of Nai Ki Thari belongs to group 1 (hard rock aquifer), which consists otherwise of all wells located in and around Khara Kuaa, (2) group 2 (alluvial aquifer) consists mainly of wells in Nai Ki Thari and the plain between the two study areas, but one hand pump (KK_HP20) close to Khara Kuaa also falls into this group.

The graphical evaluation using a Durov plot of the samples grouped according to the HCA, including the outliers and the surface-water samples shows that the main difference between group 1 and group 2 is the mineralization, here shown as total dissolved solids (TDS) in $\mathrm{mg} / \mathrm{kg}$, with the latter being more mineralized than the first (Fig. 3). EC values of $1,457 \mu \mathrm{S} / \mathrm{cm}$ in the historic water reservoir and of $1,082 \mu \mathrm{S} / \mathrm{cm}$ in the Taalaab are lower than in most groundwater samples. 


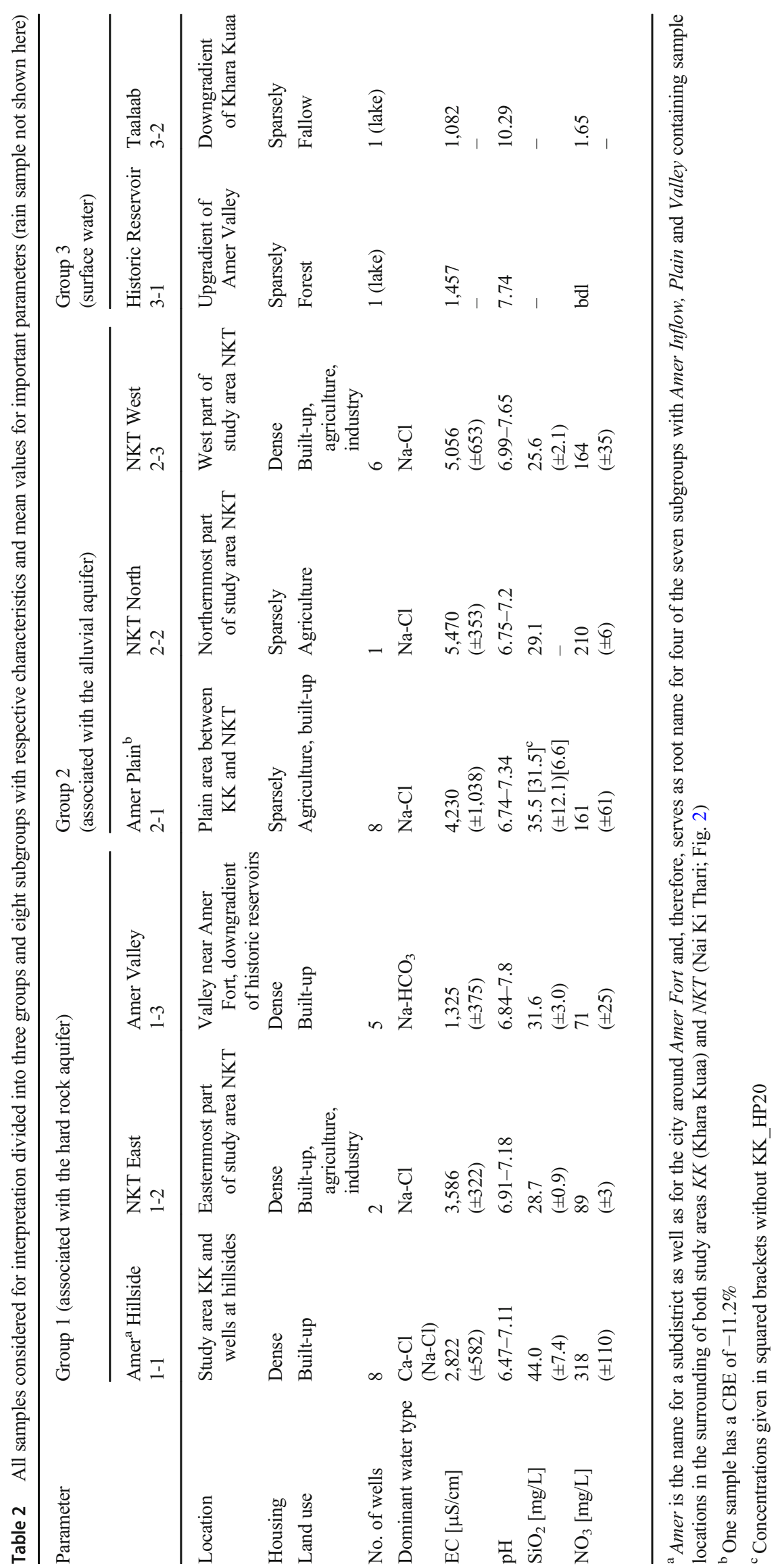




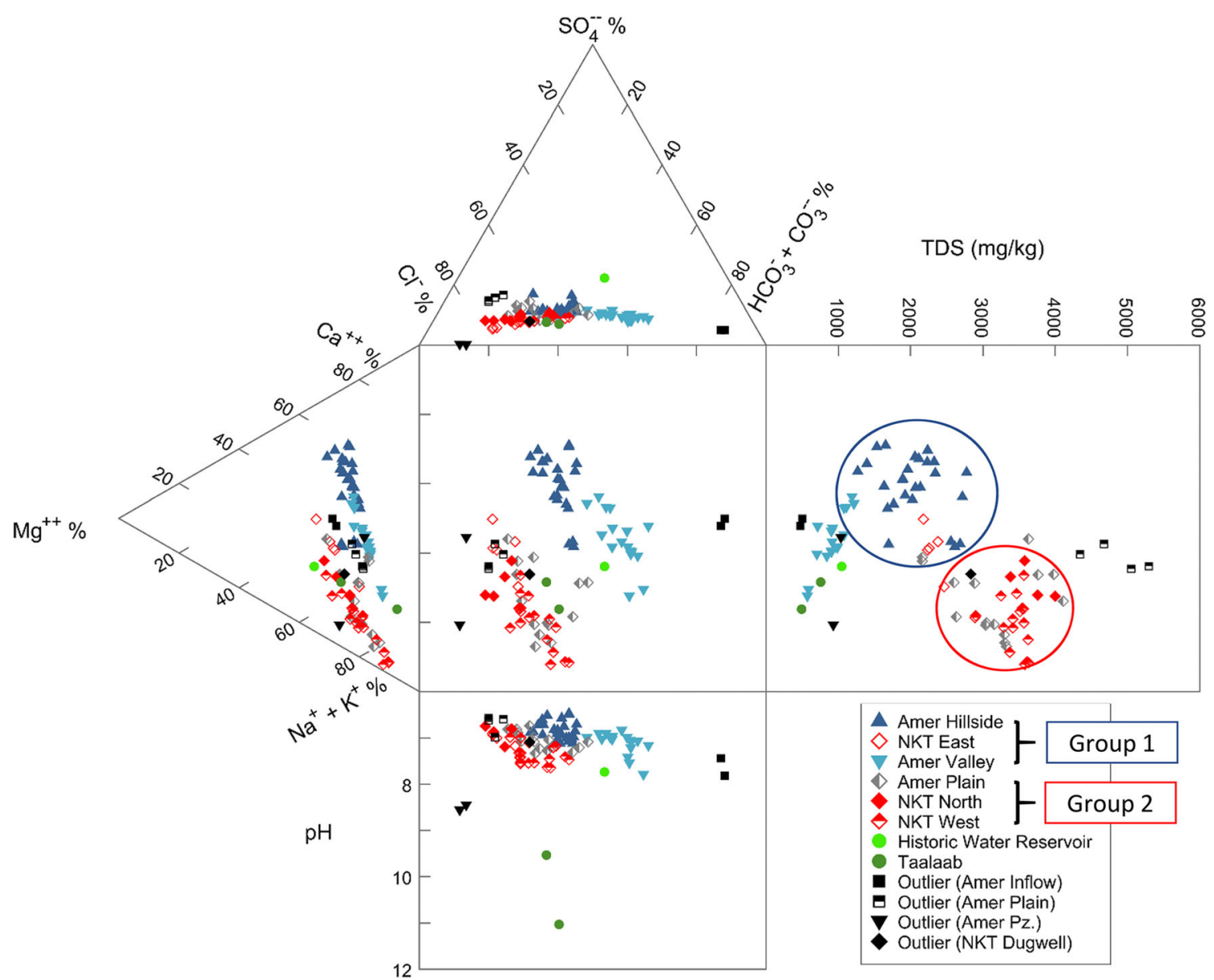

Fig. 3 The differences between the two HCA groups (blue circle: group 1, red circle: group 2,) can be also seen in the Durov plot

\section{Hydrochemical characterization of subgroups}

Groups 1 and 2 were divided into three subgroups each, while group 3 was divided into two subgroups (Table 2).

Subgroup 1-1 (Amer Hillside) The subgroup Amer Hillside consists of all four hand pumps located in the study area Khara Kuaa (KK HP01, KK HP02, KK HP15, KK HP16), one bore well located close to it (KK_BW03) and three more hand pumps in the wider surroundings but also located close to hills (KK_HP10, KK_HP24 and KK_HP04; Fig. 2). EC values in all 26 samples from the eight locations vary between 1,521 and 4,060 $\mu \mathrm{S} / \mathrm{cm}$ (average 2,822 $\pm 582 \mu \mathrm{S} / \mathrm{cm}$ ). This corresponds to TDS between 1,272 and $2,722 \mathrm{mg} / \mathrm{L}$, exceeding by far the acceptable limit of $500 \mathrm{mg} / \mathrm{L}$ given by the Bureau of Indian Standards (2012), with 14 samples even exceeding the permissible limit (in absence of alternate source) of 2,000 mg/L. However, it is still the second lowest mineralized subgroup in the investigated area after subgroup 1-3 Amer Valley (Table 2). The groundwater chemistry is dominated by $\mathrm{Ca}-\mathrm{Cl}$ except for two samples, KK_HP10 and KK_HP24, which show a Na-Cl water type. $\mathrm{SiO}_{2}$ concentration is, with $44.0 \pm 7.4 \mathrm{mg} / \mathrm{L}$, the highest of the area (Table 2). All samples show high nitrate concentrations between 125 and $555 \mathrm{mg} / \mathrm{L}$. The groundwater of KK_BW03 always shows concentrations $>20 \%$ meq $\mathrm{NO}_{3}$ and the samples from KK HP01, KK_HP02 and KK_HP16 always have concentrations $>15 \%$ meq $\mathrm{NO}_{3}$ related to the total anion concentration.

Subgroup 1-2 (NKT East) Two wells, situated at the eastern end of the study area Nai Ki Thari, fall into this subgroup (NKT_BW25, NKT_BW42). They have a higher ECbetween 3,280 and $3,950 \mu \mathrm{S} / \mathrm{cm}$ - than the samples of subgroup 1-1, but still considerably lower than the average EC of group 2. The groundwater shows a $\mathrm{Na}-\mathrm{Cl}$ water type and one of the highest $\mathrm{SiO}_{2}$ concentrations (up to $29.3 \mathrm{mg} / \mathrm{L}$ ) compared to the other wells located within the study area Nai Ki Thari. The nitrate concentrations of $80-100 \mathrm{mg} / \mathrm{L}$ are comparatively low but still exceed the Indian drinking water threshold value of $45 \mathrm{mg} / \mathrm{L}$ by twofold (Bureau of Indian Standards 2012). The similarity of NKT East to samples from Khara Kuaa (Amer Hillside) is mainly coming from a comparable TDS and the main cation concentrations, namely $\mathrm{Ca}$ and $\mathrm{Mg}$ (Fig. 3). 
Subgroup 1-3 (Amer Valley) The groundwater in Amer Valley (KK_HP03, KK_HP19, KK_HP23, KK_BW02, KK DW03), situated next to the study area Khara Kuaa and downgradient of the historic water reservoirs shows comparatively low EC values between 760 and 1,951 $\mu \mathrm{S} / \mathrm{cm}$ with an average of $1,325 \pm 375 \mu \mathrm{S} / \mathrm{cm}$. Unlike the groundwater in Amer Hillside (subgroup 1-1), the dominating anion is $\mathrm{HCO}_{3}$ followed by $\mathrm{Cl}$. On the cation side, $\mathrm{Na}$ is the main ion followed by $\mathrm{Ca}$. Nitrate concentrations do not exceed $108 \mathrm{mg} / \mathrm{L}$; the average is $71 \mathrm{mg} / \mathrm{L}$. The $\mathrm{SiO}_{2}$ concentration $(31.6 \pm 3.0 \mathrm{mg} / \mathrm{L})$ is lower than in the neighboring subgroup 1-1 (Amer Hillside) but, in consideration of the relatively low overall mineralization, it is still high.

Subgroup 2-1 (Amer Plain) Going further away from the valley and historic water reservoirs in the easterly direction, a plain area between hill ridges opens (Fig. 2). The wells from this area (KK_BW09, PHED_01, PHED_03) fall together with the wells located in the middle of the study area Nai $\mathrm{Ki}$ Thari (NKT_BW01, NKT_BW06, NKT_BW09, NKT_BW15) into the subgroup Amer Plain. In addition, one hand pump located close to Khara Kuaa (KK_HP20) belongs to this subgroup. Amer Plain shows again high EC values $(2,840-6,060 \mu \mathrm{S} / \mathrm{cm})$ and mainly a $\mathrm{Na}-\mathrm{Cl}$ water type. Including the well KK_HP20, which has the highest $\mathrm{SiO}_{2}$ concentrations $(59.3 \mathrm{mg} / \mathrm{L})$ of all samples, the average concentration would give a result of $35.5 \mathrm{mg} / \mathrm{L} \mathrm{SiO}$. However, the other samples within the subgroup show concentrations between 24 and $40 \mathrm{mg} / \mathrm{L} \mathrm{SiO}_{2}$, resulting in an average concentration of $31.5 \mathrm{mg} / \mathrm{L}$. Nitrate concentrations vary between 68 and $250 \mathrm{mg} / \mathrm{L}$. The average nitrate concentration of $161 \mathrm{mg} / \mathrm{L}$ exceeds the Indian drinking water threshold value nearly fourfold. One sample from KK_HP20 was excluded for the calculation as it shows an extreme outlier with $567 \mathrm{mg} / \mathrm{L} \mathrm{NO}_{3}$. In general, Amer Plain is the subgroup with the highest variance in all physico-chemical parameters in the associated wells.

Subgroup 2-2 (NKT North) The subgroup NKT North consists of only one well (NKT_BW41) located in the northeast part of the study area Nai Ki Thari. It is the subgroup with the highest mineralization $(5,100-5,850 \mu \mathrm{S} / \mathrm{cm})$. The groundwater is of $\mathrm{Na}-\mathrm{Cl}$ type. In contrast to the neighboring wells of $\mathrm{Nai} \mathrm{Ki}$ Thari grouped into Amer Plain and NKT West, the proportion of $\mathrm{HCO}_{3}$ in the total anion content is lower (14.3-21.6 meq\%) which also results in a lower $\mathrm{pH}$ range from 6.75-7.2. The $\mathrm{SiO}_{2}$ concentrations are $29.1 \mathrm{mg} / \mathrm{L}$, comparable to subgroup 1-2 (NKT East). Nitrate concentrations are second highest of all subgroups with values between 201 and $214 \mathrm{mg} / \mathrm{L}$.

Subgroup 2-3 (NKT West) The wells situated mainly in the western part of Nai Ki Thari form the subgroup NKT West (NKT_HP01, NKT_HP04, NKT_BW03, NKT_BW13,
NKT BW47, NKT BW49). They have the second highest average EC of $5,056 \mu \mathrm{S} / \mathrm{cm}(4,560-6,200 \mu \mathrm{S} / \mathrm{cm})$ and the highest $\mathrm{pH}$ range which is slightly alkaline (6.99-7.65). $\mathrm{SiO}_{2}$ concentration is the lowest of all groups with an average concentration of $25.6 \mathrm{mg} / \mathrm{L}$. Nitrate concentrations vary between 100 and $216 \mathrm{mg} / \mathrm{L}$ (average $164 \mathrm{mg} / \mathrm{L}$ ).

Outliers Four outliers were not grouped in the HCA analysis, of which three were discarded for further interpretation altogether. The piezometer KK_OBS02, located in the area Amer Valley (subgroup 1-3), shows similar EC values as the other samples of this area. However, the $\mathrm{pH}$ is more alkaline ( $\mathrm{pH} 8.46)$ and the water is of Na-Cl type. KK_BW08, a bore well located in the area of Amer Plain (subgroup 2-1), shows unusually high sulfate concentrations, probably resulting from anthropogenic activities. In the dug well NKT_DW02, located in the area of Nai Ki Thari, the large open surface of the well leads to DO concentrations close to oxygen saturation with all related influences on the redox chemistry. However, one of the outliers, Amer Inflow, a hand pump located in the north of both study areas, is probably not influenced by anthropogenic activities and therefore serves as a reference for pristine, uncontaminated groundwater. It shows a significantly lower mineralization than all other samples, with an EC of $576 \mu \mathrm{S} / \mathrm{cm}$.

\section{Stable isotope analyses of water samples}

The $\delta^{18} \mathrm{O}$ and $\delta^{2} \mathrm{H}$ values in 12 rain samples range from 2.4 to $-14.2 \%$, and 34.1 to $-102.2 \%$ o, respectively (Fig. 4a). They result in a local meteoric water line (LMWL) for Jaipur of $y=$ $7.8 x+9.1$. The historic reservoirs show a very wide range of $\delta^{18} \mathrm{O}$ and $\delta^{2} \mathrm{H}$ values (from 7.8 to $0.0 \%$ and 24.5 to $-12.3 \%$, respectively), while the taalaab shows only slight variations, between 1.2 and $0.2 \%$ for $\delta^{18} \mathrm{O}$, and between -8.9 and$16.5 \%$ for $\delta^{2} \mathrm{H}$ (Table S3 of ESM). The nallah samples are more negative than the other surface-water samples and plot close to the groundwater samples. The regression line through the water samples of the historic reservoir $(y=4.6 x+9.9)$ has a slope of 4.6 which is typical for evaporation lines for arid to semiarid regions (Sharp 2007). All groundwater samples, with the exception of KK_HP26, have isotopic compositions between -2.5 and $-5.8 \%$ for $\delta^{18} \mathrm{O}$ and between -21.9 and $38.8 \%$ or for $\delta^{2} \mathrm{H}$ (Fig. 4b). The most negative $\delta$-values belong to the hand pumps situated upgradient of the study areas and grouped into Amer Inflow (KK_HP08, NKT_HP12). These samples plot very close to the LMWL indicating that they are not much influenced by evaporation. The samples of the groundwater subgroups Amer Hillside, NKT East, Amer Plain, NKT North and NKT West (1-1, 1-2, 2-1, 2-2, 2-3) seem to be located on an evaporation or mixing line, while the samples of the subgroup Amer Valley (1-3) plot on a cluster around -3.4 and $-28.9 \%$ for $\delta^{18} \mathrm{O}$ and $\delta^{2} \mathrm{H}$, 
respectively. The sample from hand pump KK HP26 has much higher $\delta^{18} \mathrm{O}$ and $\delta^{2} \mathrm{H}$ values (5.7 and $17.3 \%$ ) than all other groundwater samples, and plots in the region of the historic reservoir samples (Fig. 4b).

\section{Groundwater flow and aquifer characteristics}

Based on the geoelectrical resistivity soundings, two main lithologies could be distinguished in Nai Ki Thari: alluvium and quartzite, whereby the quartzite is divided into a smaller weathered and a hard layer. The weathered layer is situated at the transition between the alluvium and the hard rock (Figs. $\mathrm{S} 1-\mathrm{S} 3$ of ESM). The alluvium has its maximum thickness in the central part of Nai Ki Thari with quartzite at depth of 50$60 \mathrm{~m}$. However, it is probable, that the hard rock was not detected with the given configuration so the thickness of the alluvium may be even greater. The shallowest occurrence of quartzite is encountered in the northeast and southwest of the investigated area (Figs. S1-S3 of ESM) with quartzite at a depth range of $30-40 \mathrm{~m}$ below ground level (mbgl). The deeper parts of the alluvium and the quartzite appear to be water saturated. The general groundwater flow direction is roughly from west to east, towards Tributary E and Dhund River (Fig. 5).
Superficial N-S striking outcrops of the quartzite in the east of Khara Kuaa probably lead to local changes of the groundwater flow direction towards the southeast.

The data of the water level logger shows the development of the water table at the quartzite aquifer from premonsoon season (end of April 2017) until postmonsoon season (end of September 2017; Fig. 6). The data gap is caused by a rapid water-table decline below the depth of the installed logger, which was then installed at a deeper level on 15 July 2017. Based on the data it can be concluded that the water table of the quartzite aquifer dropped by about $20 \mathrm{~m}$ within 2 months in the premonsoon season from May to beginning of July (red dotted line). During monsoon, the aquifer reacts within several days to rainfall events; however, all interpretation is only a rough assumption as both the data from the level logger and from the weather station are incomplete, and no corrections for changes in air pressure were done.

\section{Discussion}

Two aquifers exist in the northeastern part of Jaipur, a fractured and partly weathered hard rock aquifer and an alluvial aquifer. The geology is heterogeneous, with large variations in

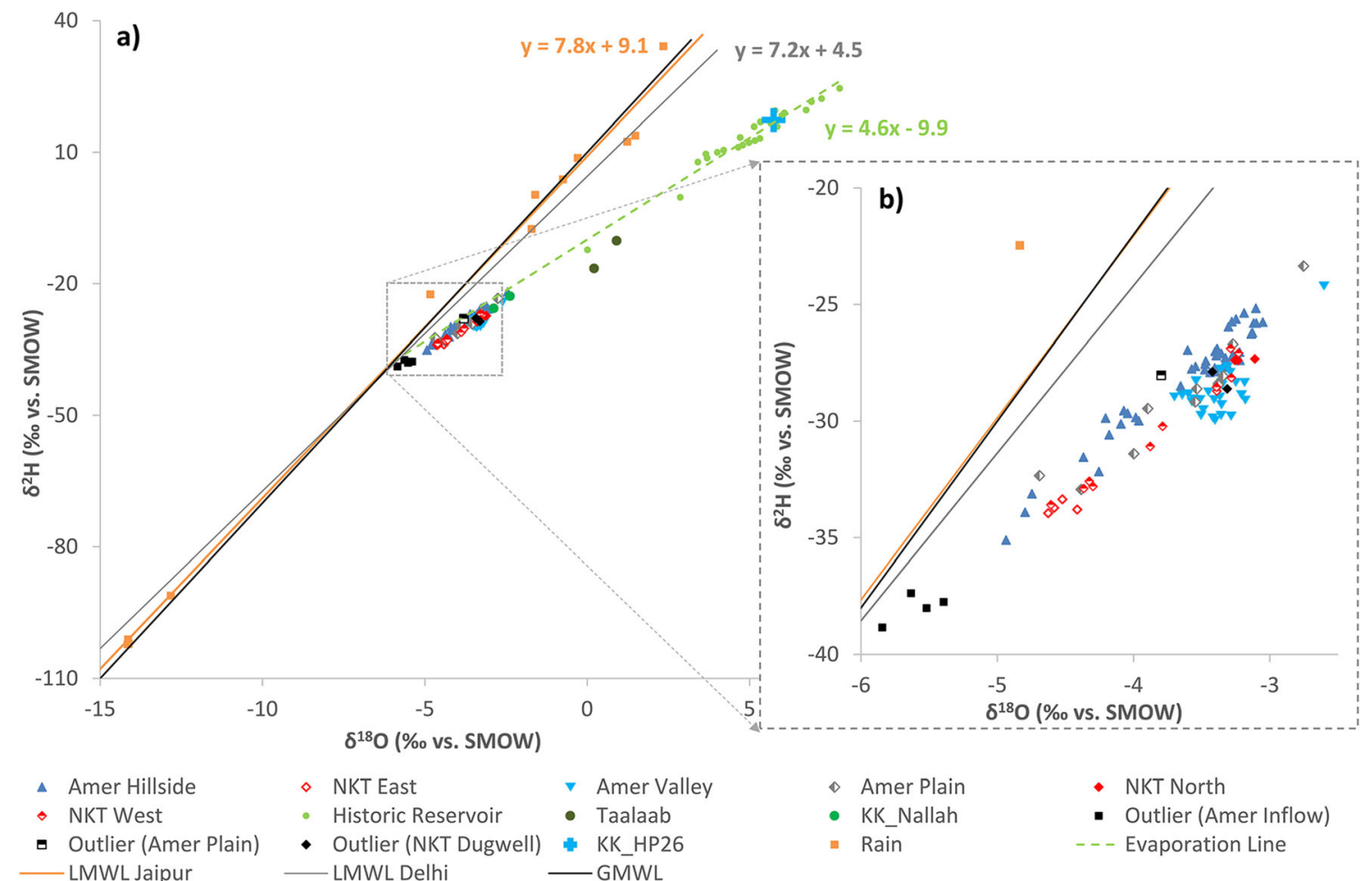

Fig. 4 a The Local Meteoric Water Line (LMWL) based on samples taken in Jaipur (orange square) is similar to Global MWL (GMWL). Surface-water samples (circles) show clear impact from evaporation. Samples from hand pump KK HP26 (blue cross), $100 \mathrm{~m}$ downgradient of the historic reservoir, show also evaporation impact. Isotopic values of

groundwater samples from hand pumps grouped into Amer Inflow are close to the rain signature indicating a recharge area. All other groundwater samples plot roughly on a line between the two end members. b Details of the groundwater isotopes plotted with LMWL and GMWL 

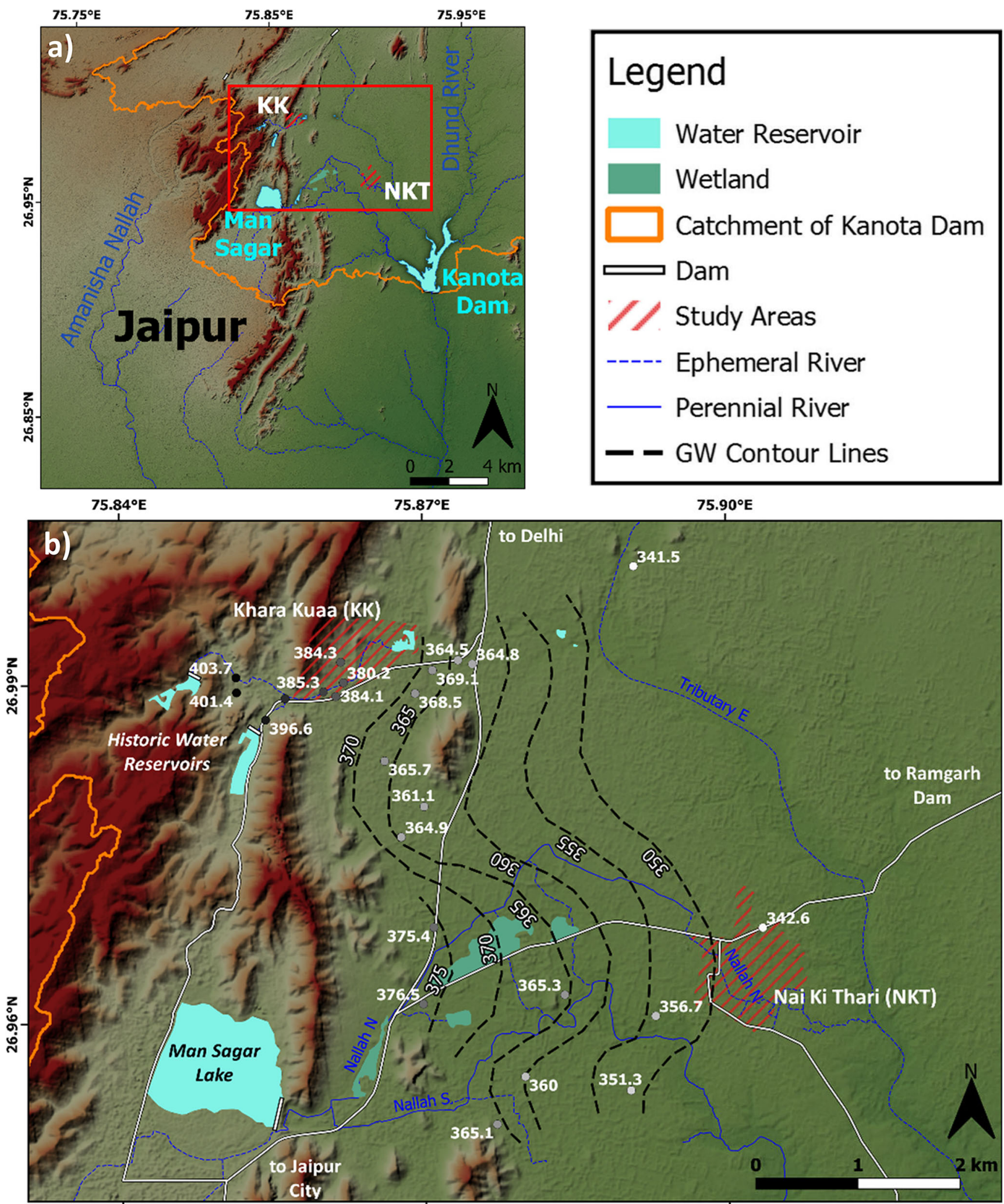

Fig. 5 a Locations of the study areas and the Kanota Dam catchment, $\mathbf{b}$ Groundwater contour lines based on premonsoon depth-to-water measurements at 24 wells, April 2017 (Table S4 of ESM)

depth-to-hard rock. A statistical analysis (HCA) of the physico-chemical parameters made it possible to group the

\section{Legend}

\section{Water Reservoir}

Wetland

Catchment of Kanota Dam

Dam

Study Areas

----- Ephemeral River

— Perennial River

\section{- - GW Contour Lines}

\section{$75.90^{\circ} \mathrm{E}$}


Fig. 6 Level logger data of the hand pump tapping the quartzite aquifer in Khara Kuaa (KK_ HP18). Red-dotted line shows the probable date range of the well running dry. Rainfall data are incomplete. Days with missing data are indicated by gaps within the blue bars. Rainfall data are retrieved for Jaipur, Sanganer weather station, from

Tutiempo.net

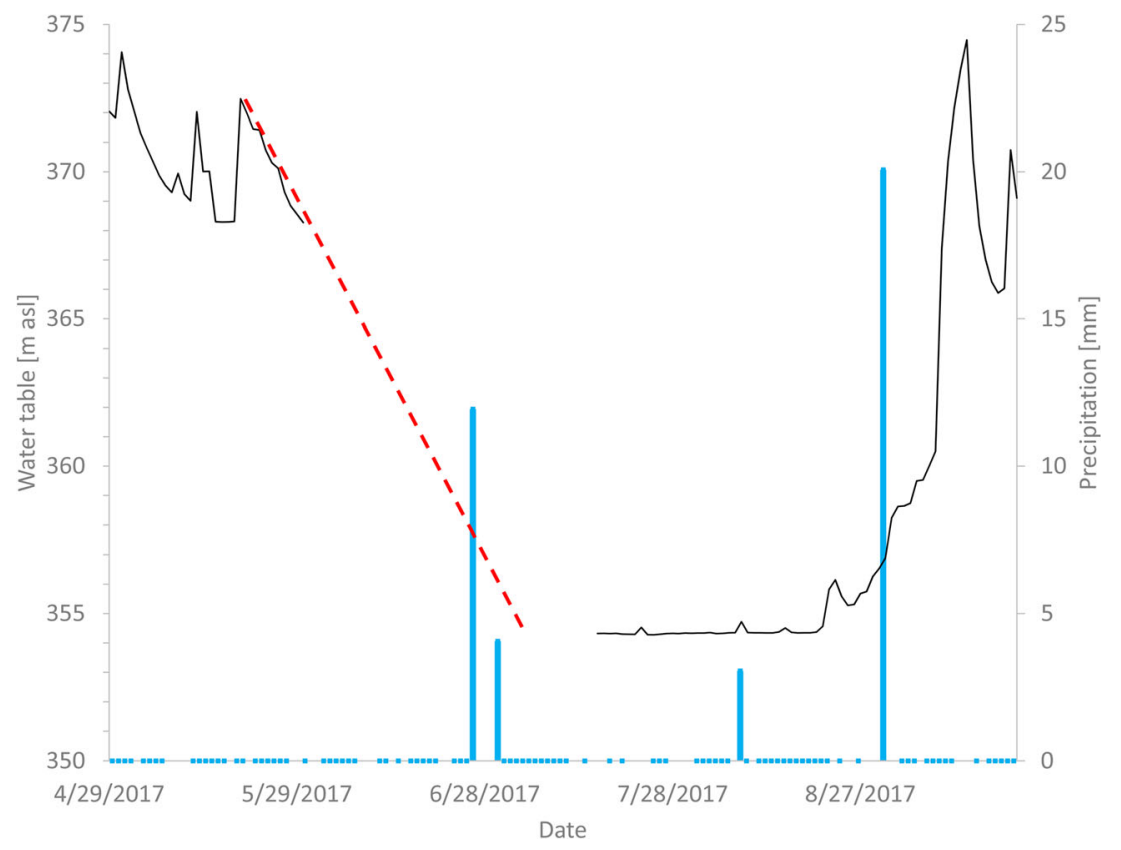

The resulting groups show that, generally, a clear distinction can be made between the two aquifers. Locally, mixing and interactions between both aquifers were identified, especially in the southeastern part of the alluvial aquifer. They show further that the historic reservoirs play a major role in groundwater recharge. These findings correspond with the processes identified through stable isotopes analysis of water samples and through water level measurements revealing a general groundwater flow direction from west to east (and locally towards the southeast).

\section{Hard rock aquifer}

Moderately high EC values, high concentrations of $\mathrm{SiO}_{2}$ and bicarbonate, and very high nitrate concentrations are the characteristics of the groundwater from the Proterozoic hard rock aquifer, which is (undiluted and not mixed) best represented by subgroup 1-1 (Amer Hillside). Samples from this subgroup were collected in an area where the hard rock crops out at the ground surface or is only covered by a thin layer of sediments $(<10 \mathrm{~m})$. The $\mathrm{SiO}_{2}$ average concentration of $44 \mathrm{mg} / \mathrm{L}$ is in the range of literature values for groundwater of quartzite rocks, being only slightly above the concentrations of $10-40 \mathrm{mg} / \mathrm{L}$ reported for the Delhi quartzite (Datta and Tyagi 1996). The weathering of silicate minerals, converting dissolved $\mathrm{CO}_{2}$ to bicarbonate (Weaver et al. 1999), is a likely origin of the high bicarbonate values.

The EC values and nitrate concentrations do not lie within the typical ranges expected in hard rock aquifers. One reason for high EC values is the semiarid climate of Jaipur. High evaporation rates and low precipitation can lead to an accumulation of soluble salts from the weathering process in the small soil cover and in the fractured parts of the quartzite which are then leached to the saturated zone during the rainy season (Garduño et al. 2011). The sources for the ions, apart from the rain itself, are feldspar, glimmer and iron-oxide minerals partly grown within the quartzite and partly filling the fractures. Microprobe analysis (results not shown here) show that for nearby hard rock samples, quartz and albite show a speckled appearance. As $\mathrm{Na}$ is well transportable in water, it is assumed that the albite developed during hydrothermal activities at greenschist-facies conditions. High nitrate concentrations are usually linked to anthropogenic activities. However, several facts point towards a geogenic origin in the hard rock aquifer. Firstly, some of the hand pumps with the highest nitrate concentrations are located in areas hardly affected by anthropogenic influences as yet (KK_HP16, KK_HP02). Latrines, sewage canals, and agriculture were not found around the wells or upgradient. Secondly, sample concentrations of up to $555 \mathrm{mg} / \mathrm{L} \mathrm{NO}_{3}{ }^{-}$exceed the concentration ranges of typical contamination of anthropogenic origin. Total nitrogen $(\mathrm{TN})$ concentrations in raw sewage influent at wastewater treatment plants (WWTPs) vary strongly, with reported values between 12 and 88 mg/L (Alemu et al. 2018; Hanson and Lee 1971; Reddy et al. 2017). TN concentrations in septic tank effluents are in a similar range (Lusk et al. 2017). Assuming that all of the nitrogen is completely converted to $\mathrm{NO}_{3}{ }^{-}$without any denitrification taking place (and without dilution) this would result in $\mathrm{NO}_{3}{ }^{-}$concentrations between 53 and $390 \mathrm{mg} /$ L. Mean nitrate concentrations of 40 and $52 \mathrm{mg} / \mathrm{L}$ are reported for intensive agricultural activities (Jacks and Sharma 1983; Vikas et al. 2015). Thirdly, increased nitrogen concentration in groundwater can be associated with weathering of bedrock nitrogen (Holloway and Dahlgren 2002)_for example, a 
geogenic nitrate contamination is reported for quartzite aquifers in Srinagar, Uttarakhand, India (Gupta et al. 2015). So, although leaking sewers and septic tanks are also likely to contribute to the nitrate contamination as well as to the high salinity, neither problem can be solved by groundwater protection measures alone.

\section{The alluvial aquifer}

Groundwater samples from the alluvial aquifer locally show different characteristics, described by the three subgroups of group 2 (Amer Plain, NKT North and NKT West). The common characteristic of all group 2 samples is high EC values, ranging from 2,840 to $6,200 \mu \mathrm{S} / \mathrm{cm}$.

In general, several processes can lead to an increase in salinity of groundwater: evaporation, especially in semiarid and arid areas, infiltration of poor water quality (grey water, irrigation water), and dissolution of minerals along the groundwater flow path (Etcheverry and Vennemann 2009; Gat 1975). The high salinity in the study area is most probably caused by a combination of these processes. Evaporation is likely to occur due to the semiarid climate of Rajasthan, which is supported by the stable isotope data that show the group 2 samples plotting on a local evaporation line. However, taking a closer look at group 2 reveals that there is no apparent correlation between isotopic enrichment and increased EC values, indicating that evaporation is not the sole source of the high salinity in the alluvial aquifer. $\mathrm{Cl} / \mathrm{Br}$ ratios (Fig. 7) of the samples point towards anthropogenic influences. Davis et al. (1998) report molar ratios for urban sewage in England (UK) and the United States from 670 to 1,350, which is similar to the ratios detected by Vengosh and Pankratov (1998) for domestic wastewater in Israel $(920-1,970)$. The wide ranges in $\mathrm{Cl} / \mathrm{Br}$ ratios of sewage can be, among others, due to variations in source water or salt intake (Katz et al. 2011). With a $\mathrm{Cl} / \mathrm{Br}$ ratio range of 550 1,100 and a $\mathrm{Cl}$ concentration range of $920-1,700 \mathrm{mg} / \mathrm{L}$, most samples from NKT West (subgroup 2-3) plot in the range of "anthropogenic and urban effects", more precisely in the range of "leaching of garbage and solid waste". Subgroup NKT North $(\mathrm{Cl} / \mathrm{Br}$ ratio: $700-1,100 ; \mathrm{Cl}: 1,350$ $2,000 \mathrm{mg} / \mathrm{L}$ ) also falls under "anthropogenic and urban effects" as well as subgroup Amer Plain $(\mathrm{Cl} / \mathrm{Br}$ ratio: 600-1,560; Cl: $550-1,700 \mathrm{mg} / \mathrm{L}$ ) which shows more variation. This corresponds with the observation that in most places, sanitation and wastewater infrastructures are missing and that solid waste is dumped at empty plots within the community. Particularly high EC values and nitrate concentrations and relatively positive isotope values of samples taken close to farming areas (subgroup 2-2 NKT North) clearly show the influence of agricultural practices (flood irrigation), and in this case strong evaporation caused by water logging (Saha et al. 2014).
These findings are in agreement with Coyte et al. (2019) who also describe the combination of natural and anthropogenic sources of salinity in Rajasthani aquifers. Therefore, protective measures alone, as in hard rock aquifers, would not solve the problem of high salinity. However, with the available data, it is not possible to determine the contribution of each source, and the success of protection measures or changes in irrigation practices would strongly depend on that.

\section{Mixing/aquifer interactions}

The characteristics of subgroup 1-2 (NKT East) strongly indicate that the two aquifers are not completely separate units, but that mixing takes place. All samples of subgroup 1-2 were taken in an area covered by Quaternary alluvial sediments; however, it is assumed that the wells tap the hard rock underlying the alluvial sediments. Geoelectrical resistivity soundings point towards a comparable shallow depth of the hard rock layer in the northeast of Nai Ki Thari (30-40 mbgl). Interviews with the well owners revealed well depths of 110-140 m. Relatively high $\mathrm{SiO}_{2}$ concentrations compared to other wells in Nai Ki Thari further support the hypothesis. Comparably more negative isotope values indicate that there might be only little evaporation taking place (in contrast to subgroup 1-1) or that there is mixing with unevaporated water. According to the groundwater contour map, the groundwater comes from the west where the Aravalli Hill Ridge is located and which is presumably a recharge area. In the hard rock, the infiltration process is faster than in the alluvium and, therefore, less evaporation out of the soil zone can take place. Mixing could occur due to the usual well construction, consisting of an open bore hole within the hard rock and a casing, often with slotted parts, only for the alluvial part. As the use of clay seals in the annular space is not a common practice, hydraulic connections between the aquifers are possible. Furthermore, mixing can take place where no aquitard, e.g. clay lenses, occurs. The available data and information lead to the conclusion that both situations are given in the study area.

Another example of mixing due to the well construction is the hand pump KK_HP20. It shows high Si concentrations similar to the wells from Amer Hillside and is situated close to Khara Kuaa but falls into Amer Plain group, suggesting that it is tapping both the alluvial aquifer and the hard rock aquifer. One sample from this hand pump has a nitrate concentration of $567 \mathrm{mg} / \mathrm{L}$ and an ammonium concentration of $20 \mathrm{mg} / \mathrm{L}$. It is supposed that a case of direct infiltration by sewage took place as the other three samples show $\mathrm{NO}_{3}$ concentrations around $200 \mathrm{mg} / \mathrm{L}$. The hand pump is not protected, is situated near to houses and on a street frequently used by animal herds. In such cases, protective measures (better well design, protection zones around wells) would be suitable measures to improve the quality of the water supply. 


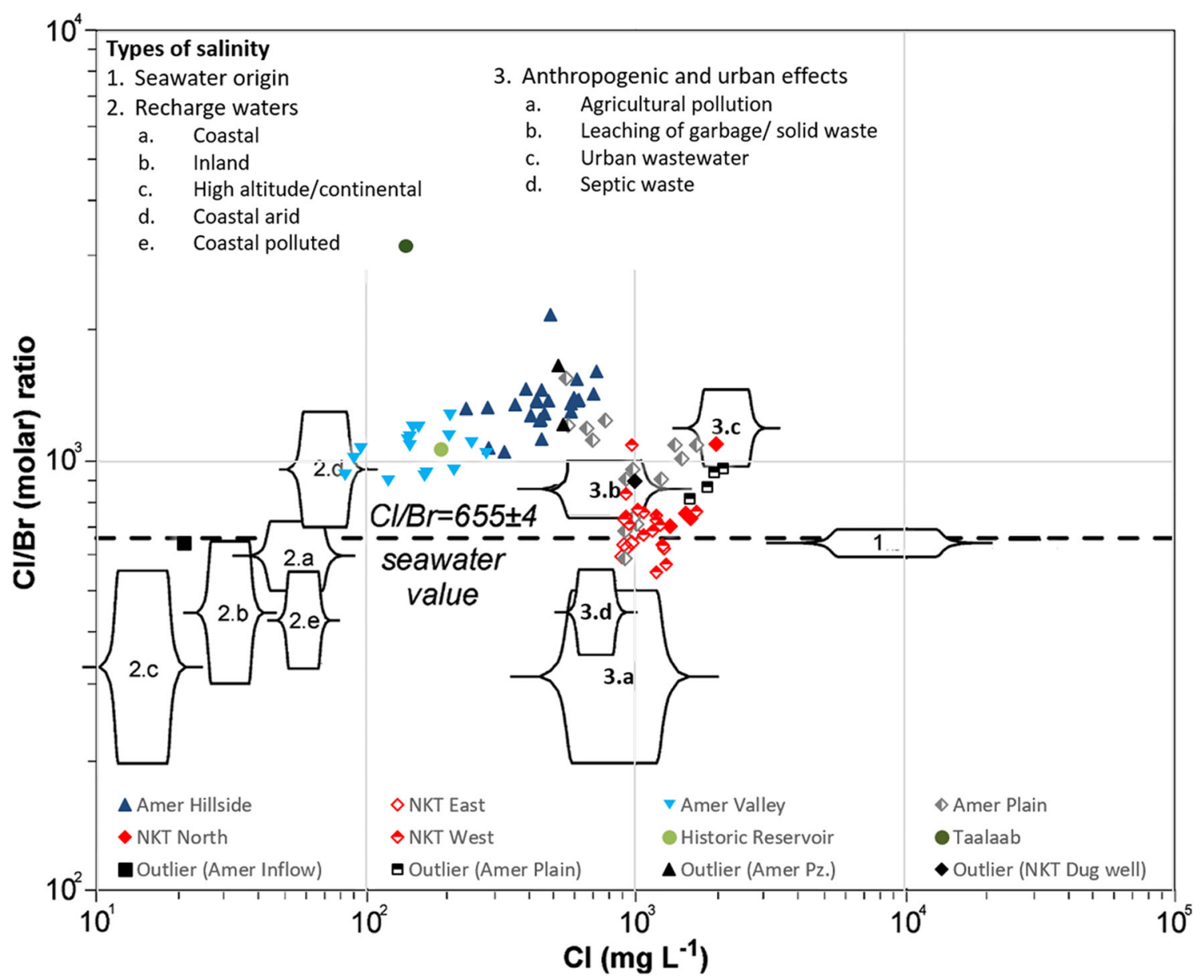

Fig. 7 Typical Cl/Br ratios for different types of salinity with own field data plotted (modified after Alcalá and Custodio 2008)

\section{Groundwater recharge and storage capacity}

Groundwater recharge takes place in the Aravalli mountain range and from the historic reservoirs located in the valleys between the hill ridges. The sample Amer Inflow, collected in the hills in the northern part of the study area (Fig. 2), is understood to most closely represent "pristine" (uncontaminated) and naturally recharged groundwater. It was collected in an area where hardly any anthropogenic influences could be observed, shows a much lower mineralization $(576 \mu \mathrm{S} / \mathrm{cm})$ than all other samples, plots in the range of recharge waters in the $\mathrm{Cl} / \mathrm{Br}$ diagram (Fig. 7) and plots closest to the LMWL of all samples, indicating that no or only little evaporation took place (Fig. 4).

In contrast, the hand pump closest to the historic reservoir (KK_HP26) shows isotope values much more positive than all other groundwater samples. Because the isotope values lie within the range of the historic reservoir samples, it is assumed that the hand pump draws a large part of infiltrated water from the historic reservoir. The samples of subgroup 1-3 (Amer Valley) also show a number of characteristics which point towards a strong influence of groundwater recharge from the historic reservoirs: Firstly, they have comparatively low EC values, with an average of $1,325 \mu \mathrm{S} / \mathrm{cm}$; although the reservoir shows a slightly higher $\mathrm{EC}$ value $(1,457 \mu \mathrm{S} / \mathrm{cm})$, as can be expected due to high evaporation losses and below-average monsoonal precipitation in the sampling year, the EC is still much lower than the EC of the ambient groundwater $(2,822 \mu \mathrm{S} / \mathrm{cm})$. Secondly, the depth-to-water measurements (Fig. 8) and the groundwater level contour map (Fig. 5) also point towards a strong influence from the historic water reservoirs. Wells tapping the hard rock aquifer close to the historic water reservoirs (blue lines in Fig. 8) show stable water tables throughout the year. Therefore, it is assumed that the groundwater of Amer Valley shares a high proportion of recharge from the historic reservoir.

Dug wells located far away from the reservoirs show high seasonal variations in groundwater levels (Fig. 8, green lines). In March 2017, wells in and around Khara Kuaa ran dry, with only two recovering again after the monsoon, indicating a low storage capacity of the quartzite aquifer. This is further supported by the level logger data showing a rapid water-table decline of about $20 \mathrm{~m}$ in 2 months (Fig. 6). The reaction time during the following monsoon season lies only in the frame of several days, implying a very low residence time in the hard rock with a high risk of fast contaminations break-throughs. 


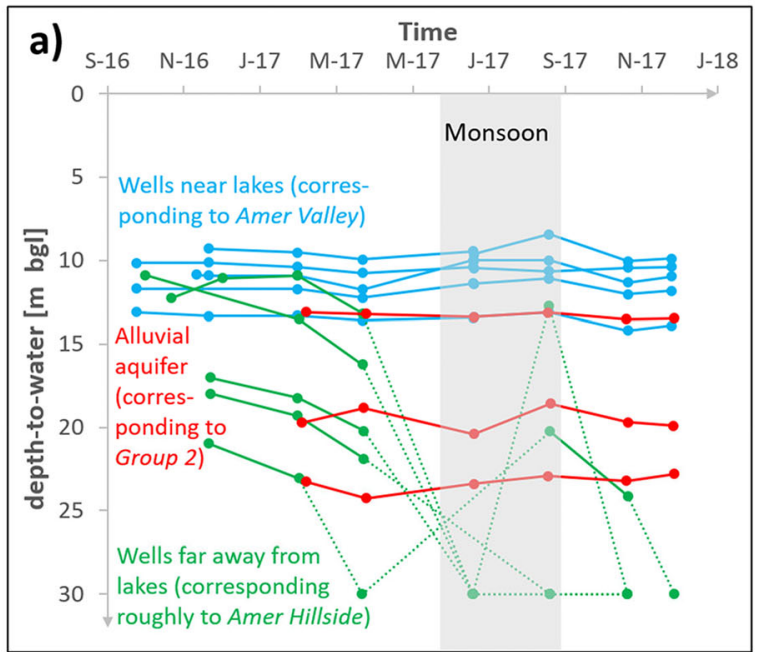

Fig. 8 a Local water-table change in the surroundings of the study area Khara Kuaa from September 2016 to January 2018. b Map of Khara Kuaa and surroundings. a-b Light blue lines represent wells directly downgradient of the historic water reservoirs (light blue circle) and green

Protection zones around and downstream of the historic reservoir would be crucial to prevent the deterioration of this comparatively good groundwater source.

For comparison, wells situated near Nai Ki Thari tapping the alluvial aquifer show much less pronounced seasonal variations (red lines in Fig. 8), indicating a higher storage capacity of the alluvial aquifer and/or a bigger catchment area.

\section{Conceptual model}

The findings are summarized in a conceptual model of the study area (Fig. 9). The visualization gives a comprehensive overview of the main hydrogeological processes and zones of

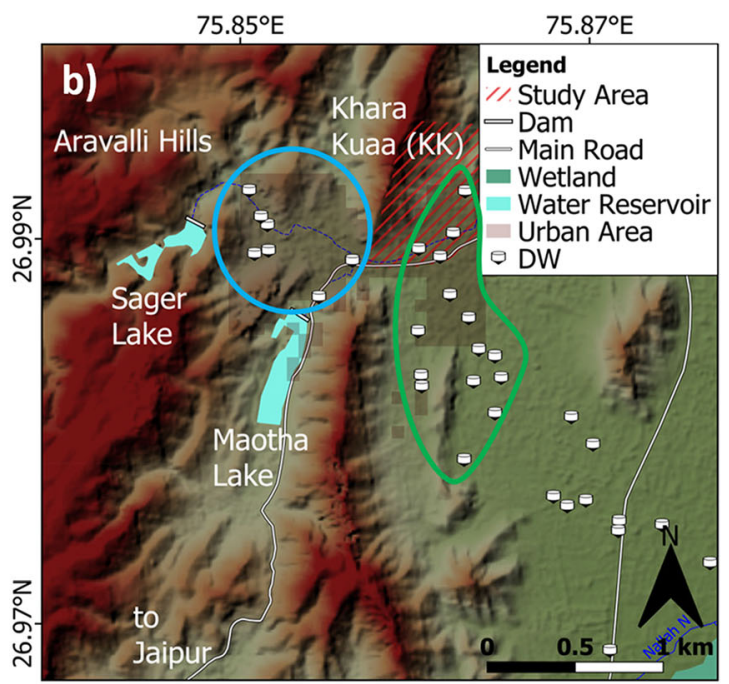

lines represent wells in the plain east of Amer Valley (green circle). Dashed lines symbolize that the wells ran dry. Red lines represent results from wells tapping the alluvial aquifer (not shown on the map)

special concern. In Nai Ki Thari, the widespread infiltration of wastewater into the alluvial aquifer increases the EC values of the groundwater. In its surrounding area (Amer Plain), irrigation practices, e.g. flooding of fields, strengthen the evaporation effect and lead to high abstraction rates. To conclude, the groundwater of the alluvial aquifer is not potable and further degradation is likely to occur.

Large seasonal variations in the water table of the hard rock aquifer make it an unreliable source for the local users. Furthermore, the results point towards a contribution to the reported high nitrate contamination through water-rock interaction. However, with the artificial reservoirs, both problems could be solved, as can be seen in the groundwater of Amer Valley, where the infiltration of surface water from the historic

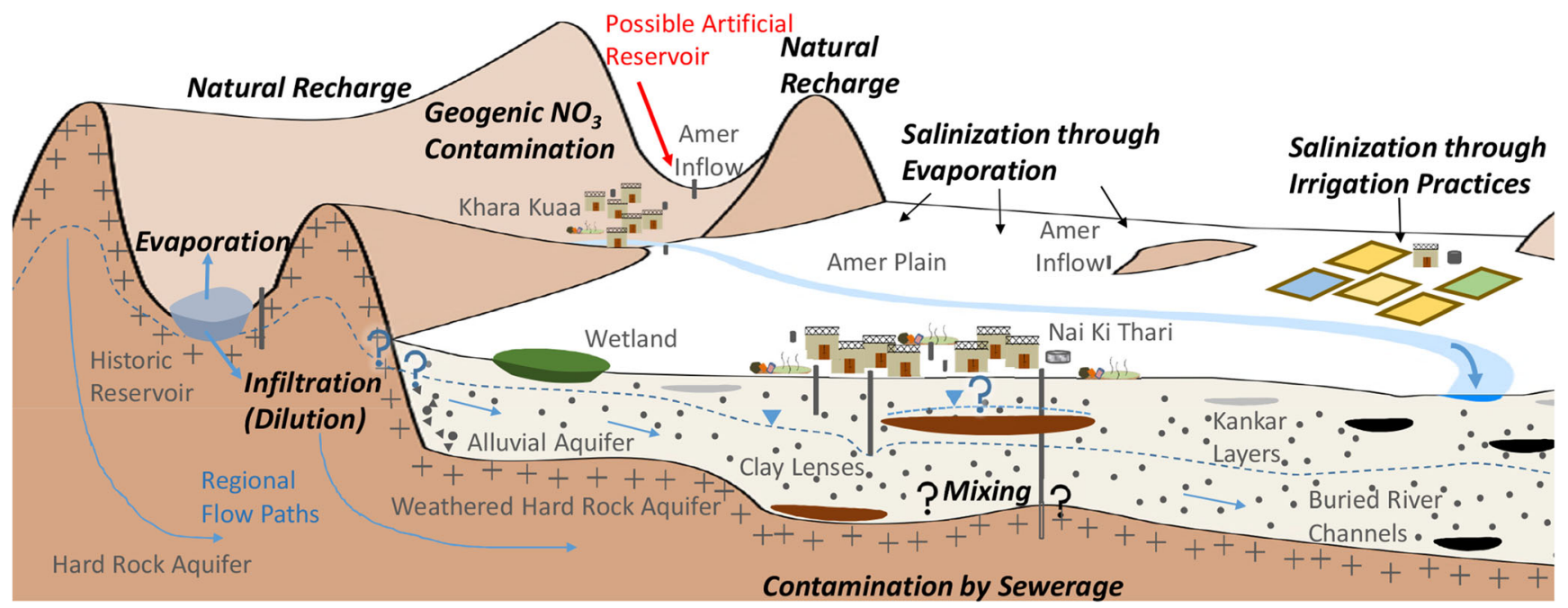

Fig. 9 Conceptual model of the study area. The Quaternary alluvium is overlying the Proterozoic fractured hard rock, which has a weathered zone at its top. Various anthropogenic and geogenic influences characterize groundwater quality and quantity 
reservoirs leads to stable water tables and a dilution of the groundwater. An artificial recharge structure, e.g. a recharge pond, could be built north and upgradient of Khara Kuaa, where there is a small valley between hills. At this geologically advantageous location, the rain that falls in this catchment area during the monsoon season could be retained. Besides the aforementioned positive effects on the groundwater, this would have the additional advantage that Khara Kuaa would be better protected against flooding, which occurs regularly during the monsoon season.

\section{Conclusion}

The groundwater of both aquifers, the overlying Quaternary alluvium and the Proterozoic fractured hard rock, is not potable, due to high TDS and nitrate values above the permissible limit (Bureau of Indian Standards 2012). For the present, the groundwater could be diluted by mixing with surface water from Bisalpur Dam, which would improve the raw water quality. This is already carried out at the municipal pump house in Amer, where the mixed water is then chlorinated and finally distributed. For the Nai Ki Thari study area, however, a pipeline for surface water would first have to be built. Furthermore, many people in the low-income areas depend directly on the local groundwater to satisfy their daily water demand. As natural sources contribute to both the high groundwater salinity and the nitrate contamination, groundwater protection measures alone will not suffice to solve these problems. To improve groundwater quality in the hard rock aquifer, artificial recharge seems to be a promising measure as this is found to work well in the hill area of Amer where infiltrating surface water from the historic reservoir dilutes the groundwater. Further detailed research would be needed before implementing a recharge pond upgradient of Khara Kuaa, including, among others, research on the catchment size, the average rainfall, the expected highest rainfall, the infiltration capacity of the soil, and the acceptance of the community, and a cost-and-benefit analysis. To determine the contribution of geogenic sources to the nitrate contamination in the hard rock aquifer, nitrogen isotope analyses and batch experiments could be carried out. To improve groundwater quality in the alluvial aquifer, sanitation and wastewater infrastructure must be installed and irrigation practices changed. However, even if these measures are taken, the groundwater would still be salty; thus, it is proposed to use community reverse osmosis systems at least until the public supply with surface water is guaranteed.

Considering the urbanization process which is especially affecting the peri-urban space, it would be advisable to start the planning and implementation of groundwater protection zones now. Any building activity in the remote hilly areas, which serve as important recharge zones, should be prohibited. The exceptional good water quality in this area (Amer Inflow) shows that it is not yet affected by anthropogenic activities. Protecting the historic reservoirs and surrounding areas should also have a high priority, as the groundwater affected by the reservoir (Amer Valley) has a comparably good quality, but is at a high risk of contamination due to short residence times and low filtering effects of the hard rock aquifer. However, further research is needed to understand how Jaipur's urbanization affects the local and regional groundwater resources. For this, it is fundamental to improve the existing monitoring network by making it not only denser but also allocating the piezometers in a meaningful way. This would involve having piezometers with each tapping only one of the two aquifers, piezometers located upgradient of the area of interest still showing pristine groundwater, piezometers at contamination hotspots, e.g. at agricultural sites, near the sewage dumping sites and within the settlements, and piezometers located downgradient of the historic water reservoirs. Such a dense and adapted network should then be used to apply a problem-oriented sampling strategy, for example focusing on seasonal changes (e.g. rapid water-table decline in the hard rock aquifer), on local hotspots (e.g. high EC values in the alluvial aquifer, possible contamination through broken hand pumps) and on surface-water/groundwater interactions (e.g. impact of historic reservoirs).

Supplementary Information The online version contains supplementary material available at https://doi.org/10.1007/s10040-021-02301-7.

Acknowledgments This research was part of the project "Women's Action towards Climate Resilience for Urban Poor in South Asia" under the guidance of the Indian NGO Mahila Housing SEWA Trust. We are grateful for hydrogeological data received from the Central Ground Water Board, Jaipur, and for the permission by the Public Health and Engineering Department, Jaipur, to sample their wells. Furthermore, the authors want to thank Mohsin Kahn, Kolja Bosch and Michael Mutz for their great support during the field work. The authors also thank the editors and reviewers for their valuable feedback.

Funding Open Access funding enabled and organized by Projekt DEAL. The project took place within the framework of the Global Resilience Partnership funded by The Rockefeller Foundation, USAID and Sida for a 2-year period (2016-2018).

Open Access This article is licensed under a Creative Commons Attribution 4.0 International License, which permits use, sharing, adaptation, distribution and reproduction in any medium or format, as long as you give appropriate credit to the original author(s) and the source, provide a link to the Creative Commons licence, and indicate if changes were made. The images or other third party material in this article are included in the article's Creative Commons licence, unless indicated otherwise in a credit line to the material. If material is not included in the article's Creative Commons licence and your intended use is not permitted by statutory regulation or exceeds the permitted use, you will need to obtain permission directly from the copyright holder. To view a copy of this licence, visit http://creativecommons.org/licenses/by/4.0/. 


\section{References}

Alcalá $\mathrm{FJ}$, Custodio $\mathrm{E}$ (2008) Using the $\mathrm{Cl} / \mathrm{Br}$ ratio as a tracer to identify the origin of salinity in aquifers in Spain and Portugal. J Hydrol 359: 189-207. https://doi.org/10.1016/j.jhydrol.2008.06.028

Alemu K, Assefa B, Kifle D, Kloos H (2018) Nitrogen and phosphorous removal from municipal wastewater using high rate algae ponds. INAE Lett 3:21-32. https://doi.org/10.1007/s41403-018-0036-1

Asoka A, Gleeson T, Wada Y, Mishra V (2017) Relative contribution of monsoon precipitation and pumping to changes in groundwater storage in India. Nat Geosci 10:109-117

Bhardwaj RM (2005) Water quality monitoring in India: achievements and constraints. Paper presented at the IWG-Env, International Work Session on Water Statistics, Vienna, 20-22 June 2005

Bureau of Indian Standards (2012) Indian standard. In: Drinking water: specification 2nd Rev. Bureau of Indian Standards, New Delhi

Butterworth J, Ducrot R, Faysse N, Janakarajan S (2007) Peri-urban water conflicts: supporting dialogue and negotiation. IRC International Water and Sanitation Centre, Delft, The Netherlands

CGWB (2007) Ground water scenario. Jaipur District Rajasthan Central Groundwater Board. Jaipur, India

CGWB (2013) Ground Water Information - Jaipur District, Rajasthan. Government of India, Ministry of Water Resources, Central Groundwater Board, Jaipur, India

Coyte RM, Singh A, Furst KE, Mitch WA, Vengosh A (2019) Cooccurrence of geogenic and anthropogenic contaminants in groundwater from Rajasthan, India. Sci Total Environ 688:1216-1227. https://doi.org/10.1016/j.scitotenv.2019.06.334

Datta P, Tyagi S (1996) Major ion chemistry of groundwater in Delhi area: chemical weathering processes and groundwater flow regime. J Geol Soc India 47:179-188

Daughney CJ, Reeves RR (2005) Definition of hydrochemical facies in the New Zealand National Groundwater Monitoring Programme. J Hydrol N Z 44:105-130

Davis SN, Whittemore DO, Fabryka-Martin J (1998) Uses of chloride/ bromide ratios in studies of potable water. Groundwater 36:338-350

Etcheverry D, Vennemann T (2009) Isotope im Grundwasser: Methoden zur Anwendung in der hydrogeologischen praxis [Isotopes in groundwater: methods for use in hydrogeological practice]. Bundesamt für Umwelt BAFU, Bern, Switzerland

Foster SSD (2001) The interdependence of groundwater and urbanisation in rapidly developing cities. Urban Water 3:185-192. https://doi. org/10.1016/S1462-0758(01)00043-7

Garduño H, Romani S, Sengupta B, Tuinhof A, Davis R (2011) India Groundwater Governance: case study. Water Paper, World Bank, Washington, DC

Gat J (1975) Elucidating salination mechanisms by stable isotope tracing of water sources. Brackish water as a factor in development, International Symposium, Beer-Sheva, Israel, Ben-Gurion University of the Negev, 5-10 January 1975, pp 15-23

Ghosh NC, Singh RD (2010) Groundwater arsenic contamination in India: vulnerability and scope for remedy. National Institute of Hydrology, Roorkee, India

Gröning M, Lutz HO, Roller-Lutz Z, Kralik M, Gourcy L, Pöltenstein L (2012) A simple rain collector preventing water re-evaporation dedicated for $\delta 18 \mathrm{O}$ and $\delta 2 \mathrm{H}$ analysis of cumulative precipitation samples. J Hydrol 448-449:195-200. https://doi.org/10.1016/j.jhydrol. 2012.04.041

GSI (2011) Geology and mineral resources of Rajasthan, 3rd edn. Geological Survey of India, Jaipur, India

Güler C, Thyne G, McCray J, Turner K (2002) Evaluation of graphical and multivariate statistical methods for classification of water chemistry data. Hydrogeol J 10:455-474. https://doi.org/10.1007/ s10040-002-0196-6
Gupta A, Ronghang M, Kumar P, Mehrotra I, Kumar S, Grischek T, Sandhu C, Knoeller K (2015) Nitrate contamination of riverbank filtrate at Srinagar, Uttarakhand, India: a case of geogenic mineralization. J Hydrol 531:626-637. https://doi.org/10.1016/j.jhydrol. 2015.10.065

Hanson AM, Lee GF (1971) Forms of organic nitrogen in domestic wastewater. J Water Pollut Control Fed 43(11):2271-2279

Holloway JM, Dahlgren RA (2002) Nitrogen in rock: occurrences and biogeochemical implications. Glob Biogeochem Cycles 16:65-165-17. https://doi.org/10.1029/2002GB001862

Howard KWF (2014) Urban-rural tensions and opportunities for co-management. Thematic Paper no. 3, Groundwater governance: a global framework for country action. FAO/Global Environment Facility, Rome

Hussain Z, Hanisch M (2014) Dynamics of peri-urban agricultural development and farmers' adaptive behaviour in the emerging megacity of Hyderabad, India. J Environ Plan Manag 57:495-515

Jacks G, Sharma V (1983) Nitrogen circulation and nitrate in groundwater in an agricultural catchment in southern India. Environ Geol 5: $61-64$

Karpouzoglou T, Marshall F, Mehta L (2018) Towards a peri-urban political ecology of water quality decline. Land Use Policy 70:485493. https://doi.org/10.1016/j.landusepol.2017.11.004

Katz BG, Eberts SM, Kauffman LJ (2011) Using cl/Br ratios and other indicators to assess potential impacts on groundwater quality from septic systems: a review and examples from principal aquifers in the United States. J Hydrol 397:151-166. https://doi.org/10.1016/j. jhydrol.2010.11.017

King AC, Raiber M, Cox ME (2014) Multivariate statistical analysis of hydrochemical data to assess alluvial aquifer-stream connectivity during drought and flood: Cressbrook Creek, Southeast Queensland, Australia. Hydrogeol J 22:481-500. https://doi.org/ 10.1007/s10040-013-1057-1

Leica (2016) Leica Viva GS14 Data sheet. Leica, St. Gallen, Switzerland

Lusk MG, Toor GS, Yang Y-Y, Mechtensimer S, De M, Obreza TA (2017) A review of the fate and transport of nitrogen, phosphorus, pathogens, and trace organic chemicals in septic systems. Crit Rev Environ Sci Technol. https://doi.org/10.1080/10643389.2017. 1327787

MacDonald AM, Bonsor HC, Ahmed KM, Burgess WG, Basharat M, Calow RC, Dixit A, Foster SSD, Gopal K, Lapworth DJ, Lark RM, Moench M, Mukherjee A, Rao MS, Shamsudduha M, Smith L, Taylor RG, Tucker J, van Steenbergen F, Yadav SK (2016) Groundwater quality and depletion in the indo-Gangetic Basin mapped from in situ observations. Nat Geosci 9: $762 \mathrm{https} / / /$ doi. org/10.1038/NGEO2791

Miesch AT, Barnett PR (1976) Geochemical survey of Missouri: methods of sampling, laboratory analysis, and statistical reduction of data. US Government Printing Office, Washington, DC

Newman BD, Havenor KC, Longmire P (2016) Identification of hydrochemical facies in the Roswell Artesian Basin, New Mexico (USA), using graphical and statistical methods. Hydrogeol J 24: 819-839. https://doi.org/10.1007/s10040-016-1401-3

Phillips D, Williams K, Andrews G, Clarke J, Carter M, Kinsman P, Smith D, Willis K, Bradbury I, Wu K (1999) Literature review on peri-urban natural resource conceptualisation and management approaches. DFID-NRSP Project 6949, DFID-NRSP, Sterling, Scotland

Podgorski JE, Labhasetwar P, Saha D, Berg M (2018) Prediction modeling and mapping of groundwater fluoride contamination throughout India. Environ Sci Technol 52:9889-9898. https://doi.org/10.1021/ acs.est.8b01679

Prakash A, Singh S (2014) Water security in peri-urban South Asia: adapting to climate change and urbanization. SaciWATERs. India, Hyderabad, India 
Rao NS (2008) Factors controlling the salinity in groundwater in parts of Guntur district, Andhra Pradesh, India. Environ Monit Assess 138: 327-341

Reddy YK, Adamala S, Levlin EK, Reddy K (2017) Enhancing nitrogen removal efficiency of domestic wastewater through increased total efficiency in sewage treatment (ITEST) pilot plant in cold climatic regions of Baltic Sea. Int J Sustain Built Environ 6:351-358

Saha D, Singh B, Srivastavai S, Dwivedi S, Mukherjee R (2014) A concept note on geogenic contamination of ground water in India with a special note on nitrate. CGWB report, CGWB, Jaaipur, India

Sanford RF, Pierson CT, Crovelli RA (1993) An objective replacement method for censored geochemical data. Math Geol 25:59-80. https://doi.org/10.1007/bf00890676

Sekhar S, Nair M, Reddy AV (2005) Are they being served?: citizen report card on public services for the poor in peri-urban areas of Bangalore. Association for Promoting Social Action and Public Affairs, Bangalore, India

Sharma RS (2009) Cratons and fold belts of India. Springer, Heidelberg, Germany

Sharp Z (2007) Principles of stable isotope geochemistry, 1st edn. Prentice Hall, Englewood Cliffs, NJ

UN-Habitat, ESCAP (2015) The state of Asian and Pacific cities 2015: urban transformations - shifting from quantity to quality State of cities. Regional reports, UN-Habitat, ESCAP, Nairobi, Kenya, 204 $\mathrm{pp}$

Vengosh A, Pankratov I (1998) Chloride/bromide and chloride/fluoride ratios of domestic sewage effluents and associated contaminated ground water. Groundwater 36:815-824. https://doi.org/10.1111/j. 1745-6584.1998.tb02200.x

Vikas C, Kushwaha R, Ahmad W, Prasannakumar V, Dhanya PV, Reghunath R (2015) Hydrochemical appraisal and geochemical evolution of groundwater with special reference to nitrate contamination in aquifers of a semi-arid terrain of NW India. Water Qual Expo Health 7:347-361. https://doi.org/10.1007/s12403-014-01551

Weaver JMC, Talma A, Cavé L (1999) Geochemistry and isotopes for resource evaluation in the fractured rock aquifers of the Table Mountain Group. Water Research Commission, Pretoria, South Africa

Yadav SS, Kumar L, Dey A (2016) Groundwater Year Book 2014-2015: Rajasthan State. Regional Office Data Centre, Central Ground Water Board - Western Region, Jaipur, India

Publisher's note Springer Nature remains neutral with regard to jurisdictional claims in published maps and institutional affiliations. 